2020, Volume 14, International Conference Innovative Business Management \& Global Entrepreneurship (IBMAGE 2020), pages: 553-567 | https://doi.org/10.18662/lumproc/ibmage2020/40

\section{Durable \\ Development, in the Context of 2014-2020 ESI Funds}

\section{Florin DIACONESCU 1}

${ }^{1} \mathrm{PhD}$., National Institute for Economic Research "Costin C. Kiritescu” (INCE), Romanian Academy, Bucharest, Romania, diaconescu1973@yahoo.com
Abstract: The theme of the sustainable development, one of the current fundamental paradigms, in which the future is forecast and planned as a balance between economic growth, social equity and environmental protection, is increasingly in vogue nowadays and in the Romanian space as a result, mainly, of the fund of European and international regulations. Used daily by all of us, in its narrow sense, the concept of development has in its series synonymous terms such as: progress, evolution, growth, enhancement, expansion, advancement, propagation etc., as well as meanings covering the complex meanings, economic development, mental, social, sustainable development and so on. With regard to the concept of sustainable development, we underline the existence, in the Romanian language, of two relatively similar concepts: sustainable development and sustainability, which we will present in comparison below. So the research started due to the need to identify an answer to the global question what to do... give up development and stop progress? This paper aims to present the existing inter-conditions between elements such as: Sustainable Development and 20142020 ESI Funds in response to this question. Therefore, further, we will operationally define the specific concepts, in relation to the European and national context, and we will present the benefits conferred on sustainable development by the European funds. Last but not least, we will present the potential of projects, funded by 2014-2020 ESI funds, to support Romania's sustainable development.

Keywords: durable development/sustainability; European funds; economic growth; social equity; environmental protection.

How to cite: Diaconescu, F. (2020). Durable Development, in the Context of 2014-2020 ESI Funds. In In M. W. Staniewski, V. Vasile, \& A. Grigorescu (vol. ed.), Lumen Proceedings: Vol. 14. International Conference Innovative Business Management \& Global Entrepreneurship (IBMAGE 2020) (pp. 553-567). Iasi, Romania: LUMEN Publishing House. https://doi.org/10.18662/lumproc/ibmage2020/40 


\section{Introduction}

Taking into account the current context, in which Romania must and is obliged to take advantage of the existing financial opportunities by implementing European projects in order to promote coherent policies, with the objective of continuing and deepening the process of modernization of Romanian society, involving both the economic and institutional consolidation and the increase of the living standards of its citizens, we considered it necessary to explore, in this way, and to present both the major importance of the field of European funds and its extraordinary potential for sustainable development.

At the same time, reconsidering another key variable of the theme of our research, essential for the well-being of any society, the problem of limited resources, in the context of sustainable development or, in short, the galloping increase in demand for resources compared to the decrease in their capacity to obtain them, and the theme of resource use in an efficient manner, naturally directed our scientific analysis towards the study of funding sources, related to the 2014-2020 programming period, ESI Funds, which, accessed, can contribute and support the implementation of sustainable development in our country.

Also, one result that we have foreseen for this article is the innovative presentation of the existing interdependencies between the key concepts of our theme: 2014-2020 ESI Funds - Sustainable Development (viewed through the sphere of the trinomial economy - equity (social) ecology (environment).

\section{Problem Statement}

Without exaggerating, we can say that environmental problems, in general, and the way in which humans endanger the ecosystem, in particular, have been among the concerns of human society since the time of prehistoric societies, a period since the first rules and taboos concerning the use, protection and rational exploitation of certain common resources. Similarly, the natural resources that supported everyday life were found in the representations, paintings, traditions and rituals of communities living in close communion with nature. Nor should it be forgotten that the decline or even disappearance of some cultures has been attributed to natural disasters.

However, the impact of human actions on the environment becomes indeed dramatic only with the Industrial Revolution of the late 18th century 
and the beginning of the 19th century, when the first approaches to the human and environmental relationship grouped [6] around three major directions (1850-1950): first, the egocentric approach, a romantic vision, oriented towards the preservation of natural resources, which acquires intrinsic value, nature being seen by the representatives of this approach Henry David Thoreau, John Muir, John Keats, Percy Bysshe Shelley etc. - as an antidote to the industrialization of society; the second, the deeply anthropocentric approach [6], pragmatic, directed towards the conservation of natural resources and their rational management, so as to ensure their use by future generations, nature being given value by the flagship representative, George Perkins Marsh, only to the extent that it supports human life and activity; the third, composed of elements specific to the first two approaches, is based on the concept developed, in the middle of the 20th century, by Aldo Leopold, the ethic of the earth, according to which people have the moral responsibility to protect natural resources, which have intrinsic value, as well as utility to humanity. This latter approach is also considered to be the inspiration for the movement known as deep ecology [5].

After the Second World War, phenomena such as urbanization, the rise of the petrochemical industry, increasing the accessibility of automobiles reconfigured the environmental agenda and created fertile ground for scientific research in the field. The United Nations Environmental Conference, held in 1972, also brought public officials and NGO activists face to face for the first time with the aim of providing a forum for discussion and development of strategies for action.

The first work whose title contains the concept of sustainability appears in 1976 - Sustainable Society: Ethics and Economic Development work by theologian Robert L. Stivers. Also during this period, in 1987, the Brundtland Report gave legitimacy to the concerns of the international community and national government actors about the effects of uncontrolled development for the environment and which established four basic principles for public policies and the legal framework: social justice and equity (ensuring the coverage of the basic needs of all); the inclusion of environmental-specific elements in all aspects of economic and social development; strict restraint in degrading or destroying the natural and environmental resources to which both life and the well-being of future generations are linked; establishing a long-term direction in the decisionmaking process.

By chronologically following the evolution of the debates in the sphere of the concept of sustainable development, Kent E. Portney underlined the possibility of assessing its transformation as well. In this 
regard, the author identified four main derivatives of sustainable development [6]: first, sustainability, derived from biology and ecology, in correspondence with another concept, the capacity of support, evolving towards the second derivative, sustainable development, for the definition of which the economic dimension intertwines with the environmental dimension, thus resulting in alternatives such as: eco-development or ecosocial economy [5]. The third derivative targets the concept of sustainable communities (i.e. sustainable cities) by accepting the importance of the role of the local or regional, national and international level both in shaping the boundaries of the concept of sustainable development and in the integrated management of issues relating to common global resources. The fourth derivative, being durable/sustainable, specific to the current period, is borrowed from very different fields, which makes it difficult in defining it. In essence, the concept signifies a positive desirable evolution [5].

At the end of 1983, following the resolution No. 38-161 of the UN General Assembly, the United Nations Commission on Environment and Development (WCED) was established, whose appointed president was Gro Harlem Brundtland, the Norwegian Prime Minister, who gave the name of the final report of this committee, the Brundtland Report, completed after just three years of meetings and adopted unanimously [6].

Although it was initially perceived as a body set up to address environmental issues, the subject-review of the work and the results of this committee were in the centre of the concerns and the key component economic development. Thus, the novelty of the committee's report was the correlation of the two aspects viewed, up to that point, as belonging to antagonistic areas, the environment and economic development respectively. By categorically rejecting the separate approach of the two dimensions, economic and environmental, it was created the need to identify a concept bridge, integrator, identified by the members of the committee as the concept of sustainable development, the definition of which has become extremely well known, being used today in the specialised works: "sustainable development is the development that meets the needs of the present without compromising the ability of future generations to meet their own needs" [6].

Furthermore, we consider it necessary to take into account, in order to complete the picture of the concept of sustainable development, and the committee's vision of the responsibility involved, divided by a wide spectrum of game changers in both the public and private domains, the general public, civil society organisations etc [6].

A considerable part of the Brundtland Report is devoted to describing, by reference to the concept of sustainable development, fields 
such as: economy and trade, food resources, biodiversity, population, energy, industry, urban development, common resources at international level (water, air etc.), peace and security [6].

Despite being criticised for its vague, intentionally general approach to the concept of sustainable development, the Brundtland Report, viewed through an all-encompassing perspective, promotes four key principles on which public policies and the legal framework have been based: equity and social justice; environmental considerations integrated into economic and social development issues; a clear prohibition on endangering the natural resources that will underpin the life and well-being of future generations; decision-making process based on a long-term perspective.

Therefore, the classic concept of development was complemented by the contribution of another term, "sustainable", which finalises its content. Thus, sustainable development can be defined as "a process of maintaining well-being designed indefinitely in the future" [6], a development that meets and ensures the needs of the present, without, however, jeopardizing the potential for future generations to ensure their own needs [9]. Moreover, in an integrated approach, sustainable development requires economic, social, environmental, political, human, spiritual and cultural development - the basics, fundamental to achieving the three specific objectives of the "Europe 2020" Strategy: smart growth, sustainable growth and inclusive growth [9]. This concept can only be taken into account with the mandatory observance of two conditions: that the well-being of citizens must grow progressively and securely over a long reference period of time and the second one: so that today's development does not jeopardise the development possibilities of future generations. Equally, on the one hand, the need to identify a general term that responds to the pressure of finding a balance between economic and social progress and concern for the environment and natural resources on the other hand, and also that can match two realities - the need for the economy to develop, namely its actual possibilities for development - has led to the association of concepts of development and sustainable.

Summarising the characteristic elements and the correspondences presented above, Gabriela Bodea, in her book, Sustainable Development, $37^{\circ} \mathrm{C}$, defines the concept as "a process relating to all types, methods and models of economic and social development aimed at achieving and maintaining the long-term balance between the economic and natural systems, so that future generations have at least the same opportunities as those present" [1]. From another perspective, Gabriela Bodea believes that sustainable development can also be defined as progress [1]. 
Similar to the fame of the definition of sustainable development in the Brundtland Report, being the first definition found in almost all the specialised works of the field, the theory of the three Es specific to sustainable development - economy, ecology (environment) and equity (social) - was also imposed [1], that is, the three Es represent a set of values around which the process of change should be planned. Its author, Stephen M. Wheeler, argues that today the importance and attention given in the past to the economic dimension has been transferred to the ecological dimension. In the first perspective, the predominantly economical one, the social and ecological dimension are contained as subsets of values, whereas in the second ecological perspective sustainable development implies economic values as a subset of ecological and social values with a greater inclusion range [1].

Contemporary critics of the concept of sustainable development, Susan S. Fainstein and Scott Campbell, in Readings in Planning Theory [3], demonstrate that the way in which the concept is defined at present does not propose solutions for practitioners under real conditions, because all three values are in a conflicted relationship and, very often, it is almost impossible to pursue them at the same time. That is why the authors emphasise the fact that sustainable development, characterised as the balancing element of the three values - economy, social equity and ecology (environmental protection), is a utopia [6].

Equally, in the literature, the theory of the three Es of sustainable development has led to the configuration of an important principle, legitimised by the Brundtland Report and recognised by Agenda 21, the principle of integration, according to which the specific elements of environmental protection must be incorporated - integrated horizontally in all other areas related to public policy. The interdependence between the principle of integration and sustainable development can be the simplest and best noted at European Union level.

\section{Research Questions/Aims of the research}

Based on extensive documentation, as well as professional experience, in specific activities, accumulated in the field, we considered it necessary and appropriate to explore the theme of our scientific approach. As such, the assumed objectives of our research are as follows: identifying and operationally defining the concepts specific to our themes; the presentation of key concepts and theories applicable to areas of interest of our research; integrating the thematic concepts set out in a unified and wellfounded approach to the concept of sustainable development; identification 
and presentation of realities and trends of European funds, in Romania, from the perspective of relation to the notion of sustainable development, information to be made available to all interested persons.

Moreover, considering the importance of research for the development of knowledge, our first research objective is to create knowledge, namely to achieve scientific results and transfer them into socioeconomic practice in order to help shape the foundations of the new style of thought and action in order to implement in our country the concept of sustainable development. In other words, the aim of our research is to help promote the need to access 2014-2020 ESI Funds to achieve the strategic development objectives, as well as to write and implement projects that, managed with commitment, seriousness and competence, meet the needs of sustainable development, implement a series of new things that are really necessary and important for the evolution and well-being of the community. Another objective of our research is to contribute to increasing social quality by identifying solutions that support sustainable development and improve the average lifestyle.

The fundamental thesis of this scientific paper - the research hypothesis - is as follows: ESI Funds 2014-2020 are essential financial resources for managing the problem of limited resources, viewed through the prism of sustainable development, for a sustainable economic recovery, for optimising the standard of living of the entire population, and for raising awareness among the entire population of the importance of the environmental component.

How the undertaken research objectives will be pursued for the purpose of testing and validating this research hypothesis is set out below.

\section{Research Methods}

The scientific investigation methods chosen - in resonance with the specifics of this approach - to be used in our research, an explanatory and descriptive one, are cross-sectional methods - by which we aim to discover and verify the relationships between the elements, aspects, processes and variables subject to analysis for a given moment/period of time, 2014-2020 such as: the "comprehensive" method, the theory of the search for meaning and the theory of distributed knowledge. In addition, for the verification of the results, we will also call for "methodical contemplation" - the method of observation on reality and data, facts and knowledge, a method that will allow us to transfer information into the rational-logical and interpretive system. Moreover, given the complexity of our theme, we consider it necessary to apply, within the framework of the research, some causation 
methods - the full study of several units, phenomena or variables considered significant (analysis of the economic, social, and ecological dimensions of sustainable development, expected to be carried out through specific project management tools). Documentary study, analysis and interpretation, synthesis, causal explanation, comparison, induction and deduction will represent the tools of scientific research.

\section{Findings}

Following the analysis of the etymology of the concept of sustainable development, we would like to highlight the existence, in the Romanian language, of two relatively similar concepts: sustainable development and sustainability respectively.

Regarding the origin of the second concept - sustainability (in Romanian "sustenabilitate") - we specify the following aspects: it comes from the Latin words sub and tenere which translates to sustain or to preserve [6], at least a few hundred years ago, the terms sustainability, sustainable and sustainable development also entered the lexicon of the English language, from where the synonyms were borrowed after 1989 by Romanian vocabulary. Moreover, according to the DEX, sustainability is the attribute of an anthropogenic activity without depleting its available resources and without devastating its environment, thus without compromising the possibilities of meeting the needs of future generations [10].

When the concept is used with the sense of economic development of a country, a region, the term of sustainable development is preferred.

\subsection{Sustainable development in the context of the European Union}

The point from which I consider that we must initiate the descriptive approach to this topic is, of course, the manner in which sustainable development is defined and regulated in the consolidated version of the Treaty of the European Union, 2012, Title 1, Article 3, paragraph 3, as a fundamental principle and objective used throughout Community construction: "The Union establishes an internal market. It acts for the sustainable development of Europe, based on balanced economic growth and price stability, a highly competitive social market economy that aims towards full employment and social progress, and a high level of protection and improvement of the quality of the environment. It shall promote scientific and technical progress. (...)". 
Also, through the successor of the Lisbon Strategy, the Europe 2020 Strategy, a programme planned for 2010-2020, the EU has set out to create conditions for "smart, sustainable and inclusive economic growth" [4].

The most important document in the field of sustainable development, at European Union level, is considered, in the literature, to be the European Union's Sustainable Development Strategy (EU SDS), adopted by the European Council held in Gothenburg, Sweden, in 2001 [7], as an outstanding, long-term planned document based on the principles of the Rio Process [6]. In addition, the EU SDS was designed as an open document, which is constantly evolving and revised [6].

Thus, in its revised version of 26 June 2006, in order to align the internal dimension of sustainable development with international development, the EU SDS presents the single and coherent vision of the Member States on sustainable development, "economic growth, social cohesion and environmental protection go hand in hand and support each other" [13]. Similarly, the revised EU SDS identifies and proposes "education and training, research and development" [13].

During the Barroso Commission's mandate in 2010, the EU SDS was replaced by the European Union's main strategy, the Europe 2020 Strategy, which aims to transform the European Union into a knowledgebased, reduced CO2 emissions, resource-efficient economy and ensure a sustainable response to potential challenges. In addition, the Europe 2020 Strategy aims to integrate and strengthen the role of sustainability in the development of all European Union policies.

The shaping year of the concept of sustainable development, at European level and, moreover, at global level, was 2015, when world leaders, meeting at the UN General Assembly session number 70 on 25th September, adopted a new global framework for sustainable development, based on its central element - the Sustainable Development Goals (SDGs), in number of seventeen. 2030 Agenda [17] is a thematic agenda, planned for a period of 15 years, 2015-2030. Moreover, according to this document, sustainable development is presented as encompassing the socio-economic and environmental dimensions that evolve into interdependency, universal, integrated and mutually supportive [16], thus providing a new image of Europe, which can be suggestively called the social contract of the $21 \mathrm{st}$ century [14].

Today, fully compatible with the community vision on the concept of sustainable development, the 2030 Agenda, in which the EU has also played a key role, is the global main project, the promise of eradicating poverty and achieving results in the area of sustainable development, by 2030, at global level, which will be achieved through the participation of all 
countries, both developed and developing countries in achieving the Sustainable Development Goals (SDGs). The 2030 Agenda also incorporates, in a balanced manner, all three dimensions of sustainable development - the economic dimension, the social dimension and the environmental dimension - that intertwine and support each other [17].

The European Union is committed to being a leader in the implementation of the UN 2030 Agenda and the SDGs, by applying and respecting the principle of subsidiarity, by encouraging a common approach between the Union's external actions and its policies, and by better coherence between EU financial instruments [17]. In this way, sustainable development has become, at European Union level, the essential guiding principle for all European Commission policies [16].

\subsection{Sustainable development in Romania}

In Romania in the 1990s, political changes have opened the way for concerns in the field of sustainable development. Thus, in order to follow the trends already existing in the West, the first forms of environmental civil and political manifestation, NGOs and political parties, as well as the first institutions focused on environmental issues - ministry, parliamentary committees etc., have also emerged in Romania, which have developed, under the impetus of the UN deliberations, on the one hand, and under the obligations assumed as part of the declarations, agreements, conventions, agreements and treaties ratified by Romania, on the other hand, and the first regulations of the field [6]. It is important to note that Romania was the first country in Europe to ratify the Kyoto Protocol to the UN Framework Convention on Climate Change [6].

Moreover, the prospect of EU accession has driven these concerns, which materialised in 1997-1999 with Romania's first strategy for sustainable development, developed as part of a project funded by the UN Development Programme (UNDP) and adopted as an official government document [6]. After Romania's accession to the EU in July 2007, this first national strategy was the foundation and subject of the interim reporting to the Commission of the way and extent of the SDGs [2].

Although not finalised in an official document, the steps for the development and long-term adoption of a national sustainable development strategy continued in the following years, until November 2008, when, as an EU member, in line with the agreed objectives at Community level, as set out and outlined in the Accession Treaty, the Lisbon Strategy and the EU SDS revised in 2006, Romania has released the "Horizons 2013-2020-2030" Strategy [6]. 
Also, after Romania's accession to the EU, the lack of a national strategy on sustainable development, applicable and in line with the new context, was replaced by a series of programmatic documents and field strategies such as: the protocols annexed to the Treaty of Accession of Romania to the EU, signed in April 2005, which contained the concrete commitments of our country to transpose the acquis communautaire into practice; NDP 2007-2013, through which Romania's economic and social development was strategically planned and calibrated with the principles of EU cohesion policy; CSNR 2007-2013, approved by the Commission in June 2007, setting out the priorities for the intervention of the European structural funds within the framework of economic and social cohesion policy [6].

Since 2008, the National Strategy on Sustainable Development (SNDD) [15] proposes and presents the vision of Romania's development in the optics of the next two few years, through clear objectives. More specifically, for the first horizon, 2013, the objective is to transpose the principles, instruments and practices of sustainable development within all public policies and programmes of our country; for the second horizon, 2020 , the cancellation of as many economic and social dispairities between Romania and the other member states as possible and the achievement of the average level of EU countries for the most important indicators relating to sustainable development is the proposed objective; and for the third horizon, 2030, the greatest proximity of our country to the average level to be achieved in 2030 by the countries of the European Union is the key objective proposed [15]. Also among the main directions to action, set out in the SNDD text are: establishing a rational mutual link between the Sustainable Development Goals and the capacity to support natural resources; systematisation and renewal of education, health and social services systems through constant reference to demographic developments and their impact on the job market; the categorical use, in all services and production activities, of eco-efficiency criteria, using the best technologies available on the market, both economically and environmentally; developing plans of measures to early anticipate the effects of climate change and potential crisis situations resulting from natural or anthropogenic phenomena; ensuring food security and safety with the fulfilment of the requirements for soil fertility maintenance, biodiversity conservation and environmental protection; implementation of large-scale projects and/or programmes in the fields of education, health and social services, food safety, infrastructure, energy and environmental protection; protection and exploitation of national cultural and natural heritage, as well as the 
connection of our country to European quality of life standards and norms [15].

At the same time, in view of the fact that Romania has committed to implement, at national level, the European sustainable development goals, in compliance with the dynamic evolution of Community regulations, from 2017 onwards, the path has been opened up towards the revision of the National Sustainable Development Strategy. From this point of view, a series of public consultations were held at the end of 2017, with a series of public consultations taking place at the July 2018 session of the UN High Level Political Forum on Sustainable Development, at the UN headquarters in New York, Romania presenting the Voluntary National Review, through which the evolution and concrete measures adopted by our country for each sustainable development objective are presented [11].

Therefore, an important first step towards the successful management of environmental threats and vulnerabilities can be considered, according to Constantin Iordache and Diana Sima, the regulation of the legal framework, on the one hand, and the establishment of institutions with a role in monitoring and intervening in the event of natural disasters, earthquakes, forest fires, floods etc., on the other hand [8]. In Romania, in 2020, the supreme authority, at the central level, in the field of environmental protection is held by the Ministry of Environment for subdomains such as air pollution, waste management, climate change, nature protection and sustainable development, waters, forests and cynegetics.

\section{Discussions}

A first statement which we consider to be clarifying is that the ESI Funds 2014-2020 are the main financial instrument of the European Union, related to the current programming period, aimed at supporting the implementation of the three dimensions of sustainable development in Romania.

Secondly, we consider it necessary to emphasise the two distinct levels where the demands of sustainable development can be pursued, namely: the overall level of sustainable development, within all projects cofinanced by the ESI Funds, that is, the specific level at the level of the operational programmes (i.e. at the level of the priority axes and/or the investment priorities assumed by each OPO, which expressly pursue the sustainable development of Romania).

Another aspect that we also need to highlight is the focus - in the projects co-financed by the ESI Funds - on the integration of sustainable development aimed mainly at the environmental dimension if we consider 
that two of the three perspectives specific to sustainable development and security, the economic dimension and the social dimension are already contained, managed and implemented through projects financed under this financial instrument. However, as mentioned above, the dimensions of sustainable development - environmental, social and economic development aspects - must be treated integratedly, as a single theme composed of mutually supportive elements in order for development to become sustainable.

Furthermore, in the context of the projects implemented in this financial framework, Article 8 of the Common Regulation provides that the objectives of the ESI Funds must be pursued in accordance with the principle of sustainable development, with that of the EU's promotion of the objective of preserving, improving and protecting the quality of the environment, in accordance with Articles 11 and 191 (1) of TFUE, taking into account the 'polluter pays' principle. Member States and the Commission are responsible for taking all precautions to ensure that resource efficiency, biodiversity, adaptation to climate change, environmental protection, disaster resilience, risk prevention and management are considered in both the preparation and implementation of $\mathrm{AP}$ and OP [12].

Therefore, in order to materialise the specific objectives of sustainable development, projects may include cross-cutting actions, the permanent purpose of which is to organise resources of a project, so that adverse effects on the environment are mitigated or even eliminated.

Hence, we consider it appropriate to present a number of techniques specific to the environmentally friendly approach used in the project management activity: organising for the team a training session on sustainable development and practical ways of saving the resources involved in the implementation of the project; if the funder and the project budget permit, the team involvement of an expert on sustainable development issues; the development and publication of material for the presentation of planned cross-cutting activities for the dimension of sustainable development; implementing activities to make resource consumption more efficient (promoting the printing of two-sided documents; printing only documents strictly necessary to be printed; mitigating the negative impact of transport by using electronic means of communication - videoconference).

\section{Conclusions}

The human being as the main resource of European projects, as the main subject and also as the author of sustainable development is therefore 
the theme of this research, which addresses fundamental elements within the two different areas - ESI 2014-2020 funds (1) and sustainable development understood as a trinome: economic development, equity, protected natural environment (2), elements that we have analysed multidimensionally and multidirectionally. In other words, our hypothesis has been validated.

\section{References}

[1] Bodea G. Sustainable development, $37^{\circ} \mathrm{C}$. Cluj-Napoca: Presa Universitară Clujeană Publishing House. 2014.

[2] Botezatu A. Sustainable Development: from interest to intention and implementation in The CSR Report. Report No.:2/2017

[3] Fainstein SS, Campbell S. Readings in Planning Theory. 3rd ed. Chichester (UK): Wiley-Blackwell Publishing; 2011. 516 pages.

[4] Filip D, coord. Europa 2020 Strategy and the state of implementation in Romania. Bucharest: European Institute of Romania; 2014.

[5] Florescu M, Balogh N, Balogh M, Neamtu B. Project Management. Durable development - Course Support. Cluj-Napoca: Ministerul Educaţiei, Cercetării şi Tineretului. 118 pages.

[6] Gavrilă-Paven I. Sustainable Development. Course Support. Alba Iulia: 1 Decembrie 1918 University. 2014. 51 pages.

[7] Iordache C, Coman D. Community policies and strategies. Bucharest: Publishing House of Carol I National Defense University. 2010. 276 pages.

[8] Iordache C, Sima D. European and national strategies, within the international legal cooperation, for the protection of the natural environment. Bulletin of the Carol I National Defense University [Internet]. 2015 Jun [cited 2020 Oct 13];2(2). Available from: https://revista.unap.ro/index.php/revista/article/view/138/116

[9] Oprean C, Tita O, coords. Contemporary Views regarding Sustainable Development. Bucharest: Pro Universitaria Publishing House. 2015. 300 pages.

[10] Dexonline [Internet]. Sustenabilitate; [cited 2020 Aug 30]; [2 screens] Available from: https://dexonline.ro/definitie/sustenabilitate

[11] 2030 Agenda for Sustainable Development. DONUISF [Internet]. August 2017; [cited 2020 Aug 31]; Available from: https://anes.gov.ro/wp-content/uploads/2018/07/Agenda-2030pentru-dezvoltare-durabila.pdf 
[12] Guide on the integration of horizontal themes in projects funded by the ESI Funds 2014-2020 - Part II, Sustainable Development. [Internet]. 2016; [cited 2020 Aug 27]; Available from: https://www.fonduriue.ro/images/files/documenterelevante/orientari beneficiari/Ghid.egalitate. sanse.2.pdf

[13] Integrating sustainable development into EU policies: analysis report for 2009 on the EU's Sustainable Development Strategy. Communication from the Commission to the EP, the Council, the EESC and the CR. Bruxelles. [Internet]. 2009 [cited 2020 Aug 27]. Available from:

http://www.europarl.europa.eu/meetdocs/2009 2014/documents/co $\mathrm{m} / \mathrm{co} \operatorname{com}(2009) 0400 / \operatorname{com} \operatorname{com}(2009) 0400$ ro.pdf

[14] Opinion of the European Economic and Social Committee on Sustainable Development: an overview of the EU's internal and external policies, exploratory opinion. Official Journal of the European Union [Internet]. 2016 [cited 2020 Oct 11]; 2016/C 487/06. Available from: https://eur-lex.europa.eu/legalcontent/EN/TXT/?uri=CELEX:52016AE3385

[15] Government of Romania. Ministry of Environment and Sustainable Development. United Nations Development Programme. National Center for Sustainable Development. Romania's National Strategy for Sustainable Development Horizons 2013-2020-2030 [Internet]. Bucharest. 2008 [cited 2020 Oct 11]. 143 pages. Available from: https://sustainabledevelopment.un.org/index.php?page $=$ view\&nr $=623$ \&type $=504 \&$ menu $=139$

[16] The EU's vision for sustainable development. How does the EU see the implementation, together with its member states, of the UN 2030 Agenda for Sustainable Development. EC. [Internet]. [cited 2020 Aug 31]. Available from: https://ec.europa.eu/info/strategy/internationalstrategies/global-topics/ sustainable-development-goals/eu-approachsustainable-development ro

[17] The next steps towards a sustainable European future. European Action for Sustainability. Communication from the Commission to the EP, the Council, the EESC and the CR. European Union law [Internet]. 2016 [cited 2020 Oct 11]; 739 final. Available from: https://eurlex.europa.eu/legal-content/EN/TXT/?uri=COM:2016:739:FIN 